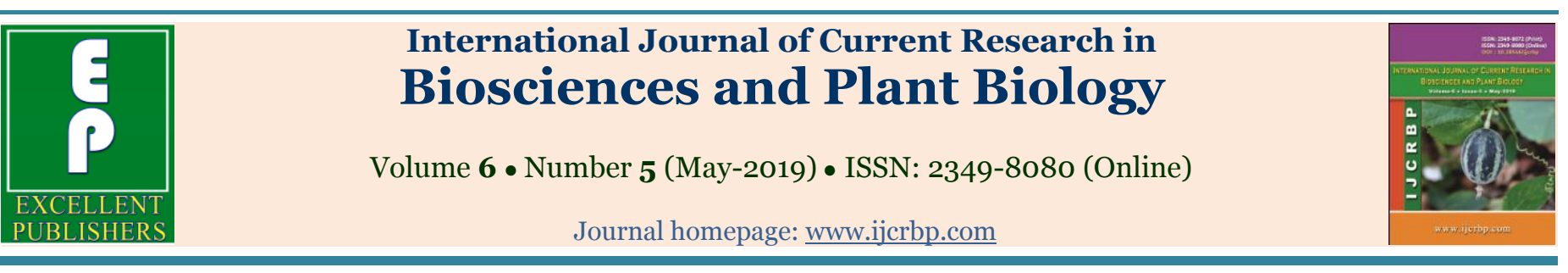

Original Research Article

doi: $\underline{\text { https://doi.org/10.20546/ijcrbp.2019.605.002 }}$

\title{
Food security situation analysis in Tharu community in Bardiya, Nepal
}

\author{
Matilal Dhakal* \\ Project Office, Save the Children, Nepal. \\ *Corresponding author; e-mail: matidhakal@gmail.com
}

\begin{tabular}{ll}
\hline Article Info & ABSTRACT \\
\hline $\begin{array}{l}\text { Date of Acceptance: } \\
\text { 21 April 2019 }\end{array}$ & $\begin{array}{l}\text { The Tharu community is indigenous ethnic group of people living mostly in Southern } \\
\text { foothills of Himalayas and inner Terai of Nepal. In this context, present study was } \\
\text { undertaken to examine the food security status and its determinants of Tharu } \\
\text { community in Bardiya district of Nepal. Primary data were collected from randomly } \\
\text { o6 May 2019 }\end{array}$ \\
$\begin{array}{l}\text { selected 72 Tharu households from Bansgadi Municipality of Bardiya district with semi } \\
\text { structured questionnaire schedule. Descriptive statistical tools, correlation analysis and }\end{array}$ \\
$\begin{array}{l}\text { logistic regression technique were used to accomplish the objectives of the study. } \\
\text { Keywords }\end{array}$ & $\begin{array}{l}\text { Findings revealed that chronic food insecure, transient food insecure and food secure } \\
\text { households were 18.06\%, 26.39\% and 55.55\% respectively. The study also showed that }\end{array}$ \\
$\begin{array}{l}\text { Food security } \\
\text { type of primary occupation and size of land holdings influenced significantly on }\end{array}$ \\
Tharu people & $\begin{array}{l}\text { household level food security status. Share cropping played a major role in coping } \\
\text { strategies by contributing11.11\% followed by self-business (8.34 \%) and service earning } \\
\text { (6.94\%) respectively. The study recommends awareness program to Tharu people so } \\
\text { that they banned to make traditional practice to make alcohol from cereal grains, } \\
\text { training in cereal production, promotion of market, job creation and income generation } \\
\text { activities. }\end{array}$ \\
\hline
\end{tabular}

\section{Introduction}

Tharu is one of the indigenous ethnic community among 59ethnicities identified in Nepal and recognized by the government as indigenous nationalities having own distinct language, culture, rituals and history. Tharu is the fourth largest ethnic groups in Nepal which consist 17,37,470 population representing $6.6 \%$ of total population (CBS, 2011). Tharu people are spread in 22 districts from Jhapa in the east to Kanchanpur in the west and inner Terai districts. There are several sub groups within the Tharu population that are scattered over most of the Terai and some inner
Terai of Nepal as Rana Tharu (Kailali and Kanchanpur district), Kathoriya Tharu (Kailali district), Sonha Tharu (Surkhet district), Dangaura Tharu (Dang, Banke, Bardiya, Kailali and Kanchanpur district), Paschuhan Tharu (Rupandehi and Nawalparasi district), Rauter Tharu (Rupandehi and Nawalparasi district), Purbaha Tharu (Rupandehi and Kapilvastu district), Aarkutwa/Chitwania Tharu (Sindhuli, Chitwan and Nawalparasi district), Kochila Tharu (Saptari, Bara, Parsa, Rautahat, Sarlahi, Mahottari and Udayapur district), Danuwar Tharu (Udayapur, Saptari and Morang district), Lampucchawa/Morangiya Tharu (Morang and 
Sunsari district) and Pahalman Tharu (Udayapur district) (Krauskopff, 1995). Tharu people have very rich and diverse food culture. Rice is major staple food while fishes, crabs, edible snail, mussels collected from river or nearby water bodies are major Tharu foods. Maghi is the biggest festival of Tharu communities and regarded as the new year. Agriculture is the primary occupation of Tharu ethnic group, and they mainly involved in farming.

The commonly accepted definition of food security is "a situation in which all people, at all times, have physical and economic access to sufficient safe and nutritious food that meet their dietary needs and food preferences for an active and healthy life" (FAO, 2008). Low income, unproductive labor, lack of autonomy, landlessness, and illiteracy are still main identity of Tharu ethnic people (Sharma, 2006). Tharu ethnic community has a traditional practice to make alcohol from cereal grain which leads perhaps to their food insecurity. Alcohol consumption is common among Tharu male, making them vulnerable to poverty and food insecurity (FAO, 2004).Bardiya district has poverty $28.7 \%$ and literacy rate $65 \%$. This district has also mal nourished problems as $50.6 \%$ of children under age five are mal nourished. Bardiya district has total population of 426576, among them, Tharu population is 226089 (53\%) (CBS, 2011).

Food insecurity is complex, social, economic and political issue. Severity of food insecurity is higher in small holders and among fewer livestock holders. The high risk to food security in the study area is the lack of access to land and low food production. Food insecurity is big problems among Tharu people and there are two types of food insecurity, one is chronic, and another is transitory food insecurity. In this context, this study was conducted to assess the status of food insecurity, its determinants and the coping strategies being adopted by Tharu community in the study area.

\section{Materials and methods}

\section{The study site and sample}

The present study was conducted in Bansgadi Municipality of Bardiya district. The study area was purposively selected for the study. Dang, Banke, Bardiya, Kailali and Kanchanpur in the western Terai and Sunsari in the eastern Terai are the districts where the proportions of Tharu populations are higher. Bardiya is the district where the proportion of Tharu people 53\% (226089 Tharu people among 426576 total population of Bardiya) is the highest than any other caste/ethnic groups. Bansgadi Municipality has 55,875 population and 11210 households, where Tharu population 31290 and Tharu households 6275 (CBS, 2011). Among these Tharu households, 72 households were selected randomly using simple random sampling technique. Semistructured and pretested interview schedule was administered among selected households using face to face interview technique to collect primary data for the study in March 2019. Well trained enumerators were hired to collect the information from the same locality. Similarly, secondary information required for the study was collected from different governmental and nongovernmental sources. This study area is representative in all social, economic and cultural variables of Tharu households.

\section{Techniques of data collection and analysis}

Tharu households are the key source of the primary data. Besides, the information obtained through semi-structured interview schedule, Focus Group Discussion (FGD) and Key Informant Interview (KII) were conducted. The information collected from the field survey was coded first and entered into the computer. Data entry and analysis was done by using computer software package like Statistical Package for Social Science (SPSS 16 version), STATA-12.1 and Microsoft Excel. Assessment of the socio-economic features of the Tharu community is carried out through the descriptive statistics. Descriptive statistics like Mean, Standard deviation, frequency count, percentage, charts and diagrams are estimated. Similarly, correlation analysis was done to assess the strength of association between food security status and different related variables like age of household head, gender of household head, type of family structure, primary occupation of household head, family size, total land holding and size of livestock holding. Besides these, logistic regression technique was employed to assess the different factors affecting the status of food security. Logistic regression of the following form was employed to accomplish the objective of the study. 
Food security status (Yes $=1, \mathrm{No}=0$ ) $=\mathrm{F}$ (Age of household head, gender of household head, type of family structure, primary occupation of household head, family size, total land holding and size of livestock holding).

\section{Results and discussion}

\section{Type and size of land holdings}

Descriptive statistic tools minimum, maximum, range, mean, standard deviation and variance were used for describing and analyzing major type of land and size of land holding. Major type of land, by the Tharu households possesses are Irrigated land and Unirrigated land, Table1 shows the size of land holding and their characteristics. Maximum size of Irrigated land was found 40 Kattha per household and unirrigated land 20 Kattha while the minimum size for the respective categories is o Kattha. Average size of land holding for irrigated land is 6.88 Kattha and unirrigated land 5.93 Kattha with standard deviation of 7.24 for irrigated land and 3.92 for unirrigated land for respective categories.

Table 1. Holdings of different types of land in study area.

\begin{tabular}{llllllll}
\hline Types and area of land & Range & Minimum & Maximum & Mean & $\begin{array}{l}\text { Std. } \\
\text { Error }\end{array}$ & $\begin{array}{l}\text { Std. } \\
\text { Deviation }\end{array}$ & Variance \\
\hline Irrigated land (Kattha) & 40 & 0 & 40 & 6.88 & 0.85 & 7.24 & 52.45 \\
Unirrigated land (Kattha) & 20 & 0 & 20 & 5.93 & 0.46 & 3.92 & 15.39 \\
Total land (Kattha) & 50 & 0 & 50 & 12.81 & 1.20 & 10.24 & 104.87 \\
\hline
\end{tabular}

Source: Field survey, 2019.

\section{Type and quantity of crops and livestock}

Major cereals production in the study area was rice and wheat. Similarly, common pulses are lentil, horse gram, pea and pigeon pea. In context of livestock and birds, cow, buffalo, goat, ship, pig, poultry and ducks were raised by Tharu households. Table 2 clearly reveals that range, mean, standard deviation, standard error and variance of crops and livestock in numerical form. Tharu Ethnic people were also fishing in local river and water bodies by using traditional fish hunting methods.

Table 2. Average production of crops and livestock reared in study area.

\begin{tabular}{llllllll}
\hline Description & Range & Minimum & Maximum & Mean & $\begin{array}{l}\text { Std. } \\
\text { Error }\end{array}$ & $\begin{array}{l}\text { Std. } \\
\text { Deviation }\end{array}$ & Variance \\
\hline $\begin{array}{l}\text { Cereal production } \\
\text { (Quintal/year) }\end{array}$ & 80 & $\mathrm{O}$ & 80 & 23.19 & 2.16 & 18.36 & 337.10 \\
Pulse production (KGs/year) & 400 & $\mathrm{o}$ & 400 & 39.39 & 7.25 & 61.55 & 3788 \\
Number of cows & 4 & $\mathrm{O}$ & 4 & 1.20 & 0.13 & 1.15 & 1.33 \\
Number of buffalos & 7 & $\mathrm{O}$ & 7 & 1.38 & 0.15 & 1.32 & 1.76 \\
Number of goats & 6 & $\mathrm{O}$ & 6 & 2.38 & 0.22 & 1.86 & 3.48 \\
Number of ships & 3 & $\mathrm{O}$ & 3 & 0.264 & 0.08 & 0.72 & 0.52 \\
Number of pigs & 3 & $\mathrm{O}$ & 3 & 0.55 & 0.11 & 0.99 & 0.99 \\
Number of poultry birds & 25 & $\mathrm{O}$ & 25 & 7.79 & 0.86 & 7.37 & 54.33 \\
Number of ducks & 5 & $\mathrm{O}$ & 5 & 0.58 & 0.15 & 1.29 & 1.68 \\
\hline
\end{tabular}

Source: Field Survey, 2019.

\section{Availability of social and institutional services}

Human and economic development of the place is greatly influenced by the availability of various social services. The list shows the distances to school for the kids, health services, Agriculture/Veterinary services, market Center, financial institutions and access to black pitch road. The availability of social services is far from
Tharu settlements. These social services directly or indirectly influence the food security status of Tharu households. Rural markets are not well developed for agriculture and livestock products and Tharu households could not get reasonable price of their produce. Due to far distance of black pitch road from these Tharu households, food price in their local market is high and this cause food insecurity also. Similarly, Bank and financial institutions are far from Tharu settlements and 
thus, less accessible of Tharu households on credit and cash investment on crop and livestock production. Table 3 shows various social services available to the study settlements. Distances to these social services were measured in minutes walking on foot distances. Various statistical interpretations are displayed in the table which speaks the range, mean value, standard deviation, standard error and variance. Average distances to school are 23.5 minutes on walking and Average distances to health service is 25.9 minutes on walking. Average distance to agriculture/veterinary Service, market center, Bank/financial institutions and black pitch road are 24.3 minutes on walking, 24.1 minutes on walking, 26.00 minutes on walking and 24.90 minutes on walking distances respectively. Tharu settlements are far remote from these social services and it indicates that there is gap of financial services like loan services as well as household savings.

Table 3. Average distance of study households to different facilities.

\begin{tabular}{|c|c|c|c|c|c|c|c|}
\hline Facilities & Range & Minimum & Maximum & Mean & $\begin{array}{l}\text { Std. } \\
\text { Error }\end{array}$ & $\begin{array}{l}\text { Std. } \\
\text { Deviation }\end{array}$ & Variance \\
\hline $\begin{array}{l}\text { School for the Kids (minutes } \\
\text { walking) }\end{array}$ & 58 & 2 & 60 & 23.50 & 1.32 & 11.27 & 132.24 \\
\hline $\begin{array}{l}\text { Health post/health centers } \\
\text { (minutes walking) }\end{array}$ & 55 & 5 & 60 & 25.90 & 1.16 & 9.87 & 97.44 \\
\hline $\begin{array}{l}\text { Agriculture/veterinary } \\
\text { Service (minutes walking) }\end{array}$ & 50 & 10 & 60 & 24.30 & 1.18 & 10.08 & 101.66 \\
\hline $\begin{array}{l}\text { Market center (minutes } \\
\text { walking) }\end{array}$ & 30 & 10 & 40 & 24.10 & 0.78 & 6.62 & 43.92 \\
\hline $\begin{array}{l}\text { Bank/financial cooperatives } \\
\text { (minutes walking) }\end{array}$ & 35 & 15 & 50 & 26.00 & 0.93 & 7.93 & 62.94 \\
\hline $\begin{array}{l}\text { Nearest black pitch road } \\
\text { head (minutes walking) }\end{array}$ & 25 & 15 & 40 & 24.90 & 0.77 & 6.57 & 43.24 \\
\hline
\end{tabular}

\section{Food security situation at household level}

The head count method of food insecurity analysis indicates that $44.45 \%$ Tharu households were food insecure and are not capable to manage food demand of their family from their own production and adopt combination of different coping strategies. The study showed that about 18.06\%Tharu households are chronically food insecure, $26.39 \%$ households are transient food insecure and only 55.55\% Tharu households are food secure (Table 4).

Table 4. Status of food security in the study area.

\begin{tabular}{ll}
\hline Classes of food security & Frequency \\
\hline Chronic food insecure & $13(18.06 \%)$ \\
Transient food insecure & $19(26.39 \%)$ \\
Year-round food secure & $40(55.55 \%)$ \\
Total & $72(100.00 \%)$ \\
\hline Source: Field Survey, 2019.
\end{tabular}

Source: Field Survey, 2019.

Table 5. Number of food insufficient months.

\begin{tabular}{llll}
\hline $\begin{array}{l}\text { Numbers of food insufficient } \\
\text { months }\end{array}$ & Frequency & Percent & Cumulative percent \\
\hline None & 40 & 55.55 & 55.55 \\
Two & 11 & 15.28 & 70.83 \\
Three & 8 & 11.11 & 81.94 \\
Four & 2 & 2.78 & 84.72 \\
Five & 1 & 1.39 & 86.11 \\
Six & 2 & 2.78 & 88.89 \\
Eight & 2 & 2.78 & 91.67 \\
Ten & 3 & 4.16 & 95.83 \\
Twelve & 3 & 4.16 & 100.00 \\
\hline
\end{tabular}

Source: Field Survey, 2019.

Tharu households were suffered from food insecurity situation. The study clearly revealed that total food insufficient month for individual Tharu households during a year. Only 55.55\% percent of 
Tharu households were food secure round the year from their own production (Table 5). Based on food insufficient months, food security is divided into 3 categories, year-round food sufficiency is food secure situation. Households with 1 to 3 months food insufficiency is transient food insecure situation and lastly those households who were faced food insufficiency of 4 or more months up to 12 months in a year are chronic food insecure situation. In this parameter, 26.39\% households were transient food insecure households who faced problems of 1 to 3 months food insufficiency from their own production, 18.06\% households faced chronic food problems or lacking foods from 4 to 12 months in a year.

\section{Coping strategies for food shortages}

Tharu households that were suffering from food security adopted different strategies to reduce, mitigate and cope with risk and shocks that affect them. Households are found to depend on different strategies to cope with food deficit situation. Wage labor was widely adapted coping strategy in the study area, particularly resource poor households are engaged in wage labor for their livelihood. They were agriculture labor and non-agriculture labor as carpentry, porter, road worker and infrastructure workers. Tharu households whose family members engaged as service in different sectors and earned money that are used to cope food deficit. Major services were school teachers, security service and skilled based jobs as mechanics of carpentry, mason and building construction in different part of country. Family members from Tharu households of the study areas were migrated to Dubai, Qatar and Malaysia for labor work and this is major family income source in these days. Businesses are commonly as vegetable production and marketing, grocery shops, hotel/restaurant and fancy shops in local market in small scale. From these businesses, Tharu households earn money and supporting to cope for food insecure situation. Table 6 shows that $11.11 \%$ Tharu households adopt share cropping to supply food for their households. Similarly, self-business adopts by $8.34 \%$ Tharu households to supply regular food for their family. In this way, $4.17 \%$ and $6.94 \%$ Tharu households are depends on wage labor and service earning respectively to supplement their family food. Remaining coping strategies are seemed small and mixed with other strategies.

Table 6. Major food management strategies for food insufficiency in study area.

\begin{tabular}{|c|c|c|}
\hline $\begin{array}{l}\text { Major food } \\
\text { strategies }\end{array}$ & Number & Percent \\
\hline Wage labor only & 3 & 4.17 \\
\hline $\begin{array}{l}\text { Wage labor and share } \\
\text { cropping }\end{array}$ & 5 & 6.94 \\
\hline Share cropping only & 8 & 11.11 \\
\hline $\begin{array}{l}\text { Service and Self } \\
\text { business }\end{array}$ & 5 & 6.94 \\
\hline Service only & 5 & 6.94 \\
\hline Self-business only & 6 & 8.34 \\
\hline $\begin{array}{l}\text { Alternative food not } \\
\text { needed }\end{array}$ & 40 & $55 \cdot 55$ \\
\hline
\end{tabular}

Source: Field Survey, 2019.

\section{Correlation analysis}

Correlation analysis was done to see the relation between food security and related variables. The magnitude and direction of relationship food security with age of household, gender of household head, type of family, type of primary occupation, family size, total land holdings and livestock holdings was analyzed. It was found that Correlation coefficient of food security status of households was positively related with age of household head, primary occupation, type of family, total land holdings and livestock holdings. Against this positive correlation, gender of household head and family size were negatively associated with food security status. Among positive correlation, total land holding was more strongly associated with food security status followed by age of household head and livestock holdings (Table 7).

Table 7. Correlation coefficient of food self-sufficiency with different related attributes.

\begin{tabular}{ll}
\hline Variable & $\begin{array}{l}\text { Correlation } \\
\text { coefficient }\end{array}$ \\
\hline Age of household head & 0.083 \\
Gender of household head & -0.025 \\
Type of family (1=nuclear, o =Joint) & 0.287 \\
$\begin{array}{l}\text { Primary occupation (1=Agriculture, } \\
\text { O=Otherwise) }\end{array}$ & 0.000 \\
Family size (number) & -0.204 \\
Total land (Ropani) & 0.611 \\
Livestock number & 0.491 \\
\hline Source: Field survey, 2019. &
\end{tabular}


Determinants of food security status were measured by using logistic regression technique. It was tried to include age of household head, gender of household head, type of family, type of primary occupation, family size, total land holdings and size of livestock holding as explanatory variables in logistic regression.
Among these, type of primary occupation was significantly and negatively affecting the food security status with odds ratio of 0.021 at 10 percent level of significance. But the total land holding was positively affecting the food security status with odds ratio of 6.281 at 5 percent level of significance (Table 8).

Table 8. Factors affecting food self-sufficiency in study area measured through logistic regression technique.

\begin{tabular}{lllll}
\hline Variable & Odds ratio & Std. Error & $\mathbf{Z}$ & $\mathbf{P}>\mathbf{Z}$ \\
\hline Age of household head & 1.028 & 0.087 & 0.33 & 0.739 \\
Gender of household head & 0.119 & 0.290 & -0.88 & 0.381 \\
Type of family (1=nuclear, o=Joint) & 156.1005 & 723.2314 & 1.09 & 0.276 \\
Primary occupation (1=Agriculture, & 0.0212 & 0.504 & -0.16 & 0.871 \\
O=Otherwise) & & & & \\
Family size (number) & 0.063 & 0.092 & -1.90 & 0.057 \\
Total land (Ropani) & 6.281 & 5.474 & 2.11 & 0.035 \\
Livestock number & 0.911 & 0.328 & -0.26 & 0.796 \\
Constant & 0.263 & 6.532 & -0.05 & 0.957 \\
\hline
\end{tabular}

Number of observations = 72; $\mathrm{LR} \mathrm{Chi}^{2}(7)=87.06$; Prob $>\mathrm{Chi}^{2}=0.000 ;$ Log likelihood = -5.9302; Pseudo R²=0.8801.

Source: Field survey, 2019.

\section{Conclusion}

Food security is still a major problem for Tharu Households of the study area. Unemployed labor force, small land holding size, low income source, poor access to education were found main characteristics of Tharu ethnic people. Existing production systems were not able for sustaining livelihood of Tharu households. They are basically food insecure people and adopt a multitude of sources like wage labor earning, share cropping, self-business and service earning to supplement their foods. Average land holding size of food secure households is almost double that of food insecure households. Land distribution system (both quality and quantity) is a major factor to maintain household level food security. This study showed that 55.55\% Tharu households were food secure, $26.39 \%$ households were transient food insecure and $\mathbf{1 8 . 0 6 \%}$ were chronic food insecure households. Another result from this study is that households adapt combination of different coping strategies as wage labor, share cropping, service, self-business, livestock raising, saving and use of loan. Similarly, total land holding is the important single factor affecting the food security status in positive way.

Following recommendations are made based on this research for the improvement of food security and livelihood of Tharu households:
$>$ Awareness program to Tharu people so that they banned to make traditional practice to make alcohol from cereal grain which leads to their food insecurity.

$>$ Cereal production training to Tharu households will be better for food production, use of hybrid/improved seed varieties will contribute for better food security situation in Tharu Households.

$>$ Market promotion program will contribute for food availability to the food insecure Tharu households.

Creation of employment opportunities and Income generation activities are helpful for accessing and utilizing food to the Tharu households.

\section{Conflict of interest statement}

Author declares that there is no conflict of interest.

\section{References}

CBS, 2010. Preliminary Result of the Population and Household Census of Nepal, Central Bureau of Statistics, Kathmandu.

CBS, 2011. National Population Census, Household and Population by Sex, Central Bureau of Statistics, Kathmandu.

CBS, 2014. Population Monograph of Nepal, Volume II (Social Demography) National 
Planning Commission Secretariat; Central Bureau of Statistics, Kathmandu.

FAO, IFAD, UNICEF, WFP and WHO. 2017. The State of Food Security and Nutrition in the World 2017. Building resilience for peace and food security. FAO, Rome.

Food and Agriculture Organization (FAO). 2004. Food Insecurity and Vulnerability in Nepal: Profiles of Seven Vulnerable Groups. ESAF, ESA Working Paper 04-10. Rome: FAO.

Krauskopff, G. (1995). The anthropology of the Tharus: an annotated bibliography. Paris.

MoAD. 2016. Food and Nutrition Security Plan of Action of Nepal. Ministry of Agricultural Development, Nepal.

MoAD. 2016. Nepal: Zero Hunger Challenge
National Action Plan (2016-2025). Ministry of Agricultural Development, Nepal.

NeKSAP. 2018. Brief on Food security situation in Nepal. Retrieved from http://www.neksap. org.np/

NPC. 2017. National Review on Sustainable Goals. National Planning Commission, Nepal.

Sharma S. 2006. NGOs in reshaping SocioEconomic Status of Tharus of Dang District in Nepal: $\quad$ www.istr.org/conferences/bangkok/ abstracts/abstract/Sharma.pdf.

World Food Program (WFP). 2006. Comprehensive Food Security and Vulnerability Analysis: http://documents.wfp. org/stellent/groups/public/documents/ena/wf po85654.pdf.

\section{How to cite this article:}

Dhakal, M., 2019. Food security situation analysis in Tharu community in Bardiya, Nepal. Int. J. Curr. Res. Biosci. Plant Biol. 6(5), 10-16. doi: https://doi.org/10.20546/ijcrbp.2019.605.002 